\title{
Translasjonsforskning i praksis
}

\author{
Norske forskere har unders $\varnothing$ kt endringer i opptaket av atorvastatin \\ etter fedmekirurgi. Overraskende fant de økt biotilgjengelighet etter \\ funksjonell forkorting av tarmen.
}
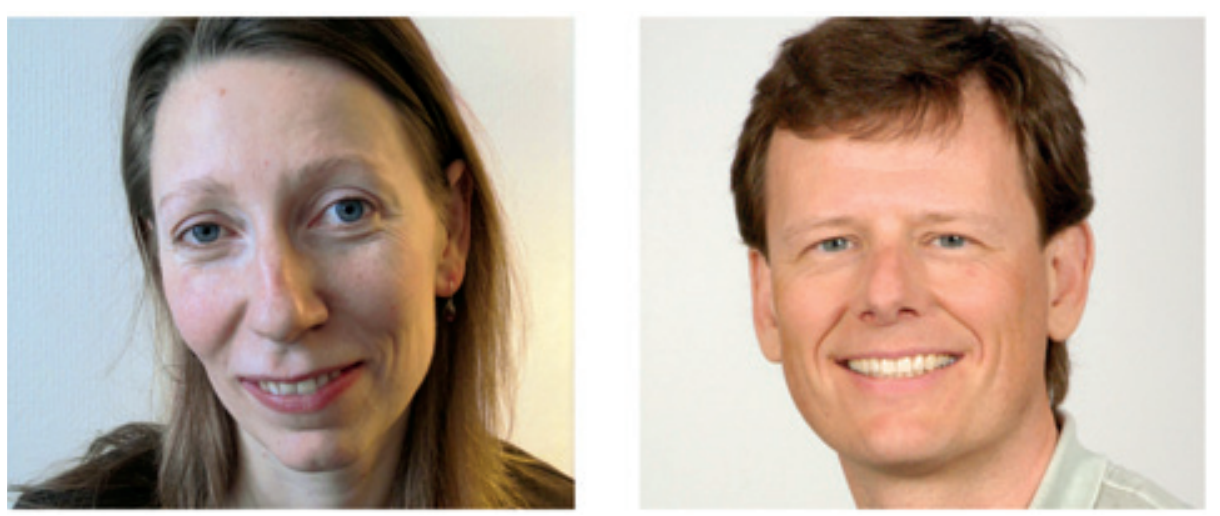

Ine Blankenberg Skottheim (foto privat) og Anders Åsberg (foto John Reierstad, Foto-og tegneavdelingen ved Det matematisk-naturvitenskapelige fakultet, Universitetet i Oslol

Forskerne studerte farmakokinetikken til atorvastatin før og etter to typer fedmekirurgi: gastrisk bypass og biliopankreatisk avledning med duodenal omkobling $(1,2)$. Før operasjonen var det som forventet store interindividuelle forskjeller når det gjaldt medikamentets biotilgjengelighet.

- Seks uker etter biliopankreatisk avledning med duodenal omkobling fant vi imidlertid en uventet gjennomsnittlig dobling i biotilgjengeligheten av atorvastatin. I samsvar med dette fant vi også en økning hos åtte av 12 pasienter operert med gastrisk bypass, sier senterleder Jøran Hjelmesæth ved Senter for sykelig overvekt i Helse Sør-Øst.

- Én mulig årsak til den økte biotilgjengeligheten etter funksjonell forkorting av tarmen kan være at den proksimale delen inneholder størstedelen av tarmens cytokrom P450-enzymer, mens de distale delene har en mindre andel metaboliserende enzymer. Ved å gå forbi den mest aktive delen av tarmen vil mer av legemidlet unngå førstepassasjemetabolisme, noe som $\mathrm{i}$ hvert fall delvis kan forklare den økte biotilgjengeligheten, sier han.

- Resultatene fra disse studiene er kanskje litt overraskende ved første blikk. Intuitivt vil man anta at en reduksjon av tarmens overflate vil føre til lavere absorpsjon av legemidler. Studien viser imidlertid at tarmen har stor kapasitet når det gjelder absorpsjon av visse substanser. Vi tror at det er tarmens metaboliserende kapasitet som er begrensende for atorvastatinets biotilgjengelighet. Denne hypotesen vil sannsynligvis også være relevant for mange andre legemidler, ettersom de enzymene som er ansvarlig for atorvastatins metabolisme, metaboliserer omtrent halvparten av alle andre legemidler.

Dersom disse resultatene blir bekreftet av andre, vil de direkte kliniske implikasjoner være at dosene til denne type legemidler må justeres på ny etter en operasjon. Det er ikke kjent om kortidseffekten også vil bestå på lang sikt. Det er mulig at tarmen adapterer seg og at dosene må justeres videre etter noe tid. Den siste hypotesen tester vi nå ut $\mathrm{i}$ oppfølgingsstudier med det samme pasientmaterialet, sier Hjelmesæth.

\section{Forskermiljøene}

Artiklene springer ut av et samarbeid mellom forskere ved Farmasøytisk institutt, Universitetet i Oslo, og Senter for sykelig overvekt i Helse Sør-Øst i Tønsberg. Forskergruppen i farmakokinetikk ved Farmasøytisk institutt ledes av professor Anders Åsberg og består ellers av av to professorer, en postdoktor og fire stipendiater, som alle jobber med individualisert legemiddelbehandling på ulike nivåer.

Forskningen i Tønsberg er i hovedsak klinisk orientert og foregår i tett samarbeid med andre institusjoner. I flere av studiene sammenliknes effekten av livsstilsbehandling og fedmekirurgi på fedmerelaterte følgesykdommer hos både ungdom og voksne, $i$ andre evalueres effekten av forskjellige konservative behandlingstiltak. Senteret har også en biobank med data fra over 2000 konsekutivt registrerte sykelig overvektige pasienter. Ved senteret arbeider to seniorforskere og sju ph.d.-stipendiater.

\section{Erlend Hem}

erlend.hem@medisin.uio.no

Tidsskriftet

\section{Litteratur}

1. Skottheim IB, Stormark K, Christensen $\mathrm{H}$ et al. Significantly altered systemic exposure to atorvastatin acid following gastric bypass surgery in morbidly obese patients. Clin Pharmacol The 2009; $86: 311-8$

2. Skottheim IB, Jakobsen GS, Stormark K et al. Significant increase in systemic exposure of atorvastatin after biliopancreatic diversion with duodenal switch. Clin Pharmacol Ther 2010; 87: 699-705.

\section{Ordforklaringer}

Fedmekirurgi: Siden 2004 har to kirurgiske hovedmetoder vært brukt i Norge. Gastrisk bypass er vanligst. Biliopankreatisk avledning med duodenal omkobling gir trolig et større vekttap og benyttes for enkelte av de tyngste pasientene. Ved dette inngrepet gjøres først en partiell, langsgående gastrektomi som begrenser volumet til magesekken. Deretter deles tynntarmen og kobles om slik at det oppstår to separate løp (ett for føde og ett for galle og bukspytt), som kobles sammen i ett fellesløp før coecum (1).

Førstepassasjemetabolisme: Betegnelse på omdanning av legemidler og andre stoffer som absorberes fra magesekk, tarm og en del av rectum til portakretsløpet (samles i leverens portvene) under den første passasjen fra absorpsjonsstedet gjennom leveren før stoffene når det systemiske kretsløpet i levervenen og vena cava. Graden av førstepassasjemetabolisme varierer sterkt forskjellige stoffer imellom, fra ubetydelig til nærmest fullstendig. For legemidler som kan gis enten som injeksjon eller som tabletter, har førstepassasjemetabolismen avgjørende betydning for hvilke doser som gis ved de to administrasjonmåter (2).

\section{Litteratur}

1. Aasheim ET, Mala T, Søvik TT et al. Kirurgisk behandling av sykelig fedme. Tidsskr Nor Lægeforen 2007; 127: 38-42.

2. Førstepassasjemetabolisme. Store medisinske leksikon. www.snl.no/.sml_artikkel/ f\%C3\%B8rstepassasjemetabolisme (21.6.2010)

Artiklene er publisert i det velrenommerte tidsskriftet Clinical Pharmacology \& Therapeutics (www.nature.com/clpt)

\section{Tips oss}

Er du iferd med å publisere eller har du nylig publisert eller har du nylig publis tidsskrift? Send tips til erlend.hem@medisin.uio.no 